\title{
Synthesis of a New [3-(4-Chlorophenyl)-4-oxo-1, 3-thiazolidin-5-ylidene]acetic Acid Derivative
}

\author{
Jacek Szczepański, Helena Tuszewska and Nazar Trotsko *(i) \\ Department of Organic Chemistry, Faculty of Pharmacy, Medical University of Lublin, 4A Chodźki, \\ 20-093 Lublin, Poland; jaacek.szczepanski.93@gmail.com (J.S.); tuszewska.helena93@gmail.com (H.T.) \\ * Correspondence: nazar.trotsko@umlub.pl; Tel.: +48-81-448-72-44
}

Received: 3 July 2020; Accepted: 23 July 2020; Published: 28 July 2020

check for updates

\begin{abstract}
The new methyl [3-(4-chlorophenyl)-2-\{[(2,4-dichloro-1,3-thiazol-5-yl)methylidene] hydrazinylidene\}-4-oxo-1,3-thiazolidin-5-ylidene]acetate was synthesized from 4-(4-chlorophenyl)1-(2,4-dichloro-1,3-thiazol-5-yl)methylidene-3-thiosemicarbazide using dimethyl acetylenedicarboxylate as thia-Michael reaction acceptor. New compounds ( 3 and 4 ) were characterized by $\mathrm{IR},{ }^{1} \mathrm{H}$ and ${ }^{13} \mathrm{C} \mathrm{NMR}$ spectroscopy methods.
\end{abstract}

Keywords: thiazolidin-4-one; Michael addition; anti-T. gondii activity

\section{Introduction}

Toxoplasmosis is a common parasitic infectious disease that occurs all over the world. Toxoplasmosis is caused by the protozoan Toxoplasma gondii, whose ultimate host is Felidae. Approximately $30 \%$ of people have positive antibodies indicating toxoplasmosis [1]. The basic danger of the disease is the possibility of congenital infections during pregnancy and the reactivation of the disease in immunocompromised persons.

Over the last decade, the scientific value of thiazolidin-4-one derivatives has increased due to their wide spectrum of biological activities, including antidiabetic, anticancer, antibacterial, antifungal, anti-inflammatory, etc. The activity and mechanisms of action of thiazolidin-4-ones are described in numerous reviews [2-7]. It is also worth paying attention to the anti-T. gondii activity of thiazolidin-4-ones [8-12].

In addition, the currently used drugs are not $100 \%$ effective for the treatment of toxoplasmosis, and this has prompted us to look for new synthetic compounds that could be used to combat this common parasite in the future.

In our previous research [12], we identified (4-oxothiazolidin-5-yl/ylidene)acetic acid derivatives with antiparasitic activity against $T$. gondii (Figure 1). The highlighted fragments (green and orange color) in Figure 1 are favorable for anti-T. gondii activity. Based on previous studies, we designed a compound which contains both highlighted fragments.

In this communication, we describe the synthesis of the previously unknown methyl [3-(4-chlorophenyl)-2-\{[(2,4-dichloro-1,3-thiazol-5-yl)methylidene]hydrazinylidene\}-4-oxo-1,3-thiaz olidin-5-ylidene]acetate, which has potential as an anti-T. gondii agent. 


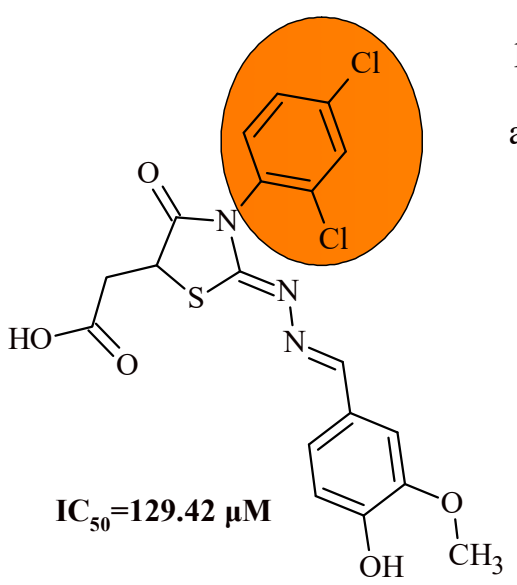

$$
\begin{aligned}
& \text { previously identified } \\
& \text { compounds with }
\end{aligned}
$$
anti-T. gondii activity

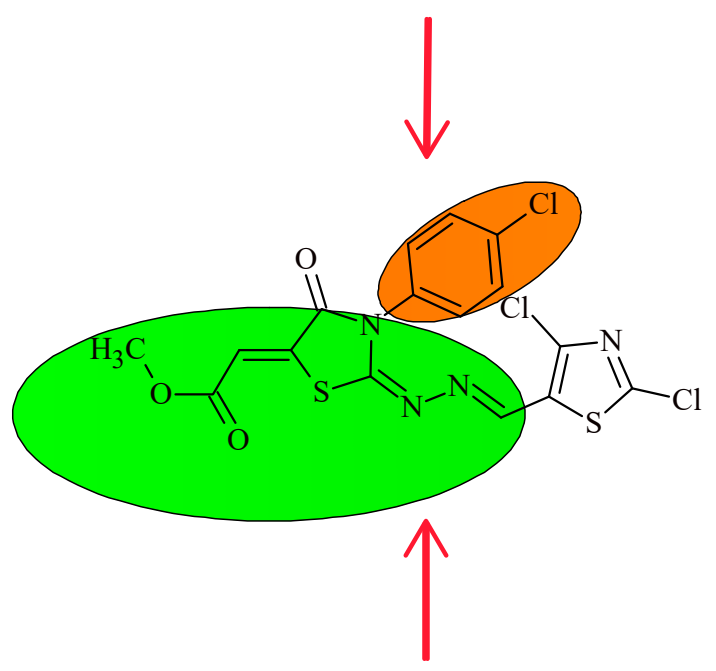

new designed compound
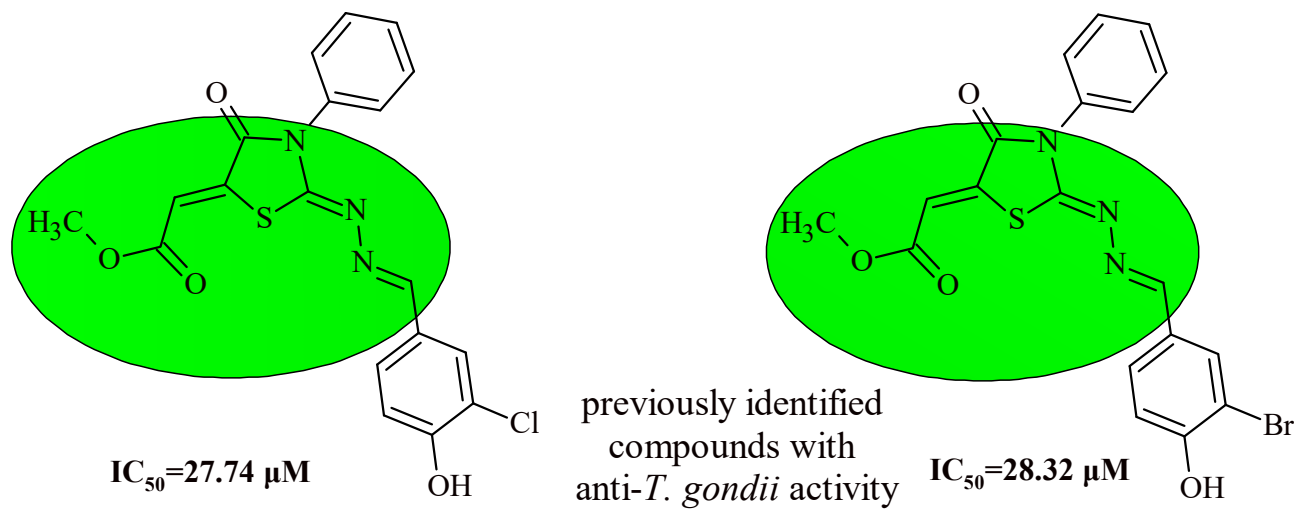

Figure 1. (4-Oxothiazolidin-5-yl/ylidene)acetic acid derivatives with anti-T. gondii activity and new designed compound.

\section{Results and Discussion}

The targeted compound was synthesized by three-step synthesis starting from thiazolidine-2, 4-dione (TZD). TZD was converted into 2,4-dichloro-1,3-thiazol-5-carbaldehyde via a Vilsmeier-Haack reaction in accordance with the literature [13]. In the next step, 2,4-dichloro-1,3-thiazol-5-carbaldehyde (2) was condensed with 4-(4-chlorophenyl)-3-thiosemicarbazide to give the thiosemicarbazone (3). In the last step of synthesis, the targeted compound was obtained from 4-(4-chlorophenyl)1-(2,4-dichloro-1,3-thiazol-5-yl)methylidene-3-thiosemicarbazide (3) and dimethyl acetylenedicarboxylate 
by thia-Michael addition of the sulfur atom to the triple bond and then cyclization to give the (4-oxothiazolidin-5-ylidene)acetic acid derivative 4 (Scheme 1), which illustrates that precursor 3 is also useful for this type of reaction, if other compounds (maleic anhydride, maleimide derivatives etc.) are used as acceptors in the thia-Michael addition.

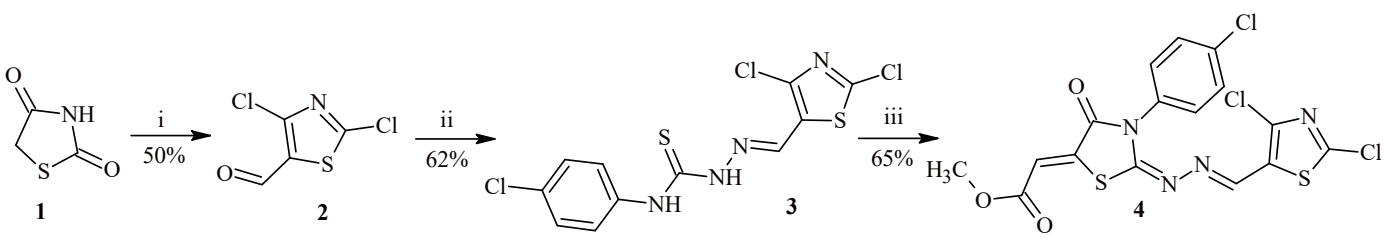

Scheme 1. Synthetic route for compound 4. Reagents and conditions: (i) $\mathrm{POCl}_{3}, \mathrm{DMF}$ stirred for 1 $\mathrm{h}$ at rt, heat for $1 \mathrm{~h}$ at $80-90{ }^{\circ} \mathrm{C}$, brought to boil and heated for another $4 \mathrm{~h}$; (ii) 4-(4-chlorophenyl)3-thiosemicarbazide, EtOH, heated under reflux for $3 \mathrm{~h}$; and (iii) dimethyl acetylenedicarboxylate, $\mathrm{MeOH}$, heated under reflux for $30 \mathrm{~min}$.

The structures of compounds 3 and 4 were supported by $\mathrm{IR},{ }^{1} \mathrm{H}$, and ${ }^{13} \mathrm{C}$ NMR spectroscopy methods (see Supplementary Materials). The ${ }^{1} \mathrm{H}$ NMR spectra exhibit the characteristic signals for para-substituted phenyl ring as two doublets in the range 7.44 to $7.76 \mathrm{ppm}$ with spin-spin coupling $J=8.7 \mathrm{~Hz}$. The signals derived from the proton of a $\mathrm{CH}=\mathrm{N}$ group were observed at $8.29 \mathrm{ppm}$ and $8.30 \mathrm{ppm}$ for compounds 3 and 4 , respectively. The characteristic proton signal of methylidene group $(\mathrm{CH}=)$ of compound 4 was observed as singlet at $6.94 \mathrm{ppm}$. All remaining signals arising from other parts of the molecule were present. Similarly, ${ }^{13} \mathrm{C}$ NMR confirmed present of all carbon atoms in molecule (details were presented in the experimental part).

\section{Materials and Methods}

\subsection{General}

All commercial reagents and solvents were purchased from either Alfa Aesar (Lancaster, UK) or Sigma-Aldrich (St. Louis, MO, USA) and used without further purification. The melting points were determined by using Gallenkamp MPD 350.BM 3.5 apparatus Sanyo (Moriguchi, Japan) and are uncorrected. The purity of the compound was checked by TLC on plates with silica gel Si $60 \mathrm{~F}_{254}$, produced by Merck Co. (Darmstadt, Germany). The ${ }^{1} \mathrm{H}$ NMR and ${ }^{13} \mathrm{C}$ NMR spectra were recorded by a Bruker Avance $300 \mathrm{MHz}$ instrument (Bruker Corporation, Billerica, MA, USA) using DMSO- $d_{6}$ as solvent and TMS as an internal standard. Chemical shifts were expressed as $\delta$ (ppm). IR spectrum was recorded by Nicolet 6700 spectrometer (Thermo Scientific, Philadephia, PA, USA). Elemental analysis was performed by AMZ 851 CHX analyzer (PG, Gdańsk, Poland) and the results were within $\pm 0.4 \%$ of the theoretical value.

\subsection{4-(4-Chlorophenyl)-1-(2,4-dichloro-1,3-thiazol-5-yl)methylidene-3-thiosemicarbazide (3)}

To the 2,4-dichloro-1,3-thiazole-5-carbaldehyde (2) (1.27 g, $7 \mathrm{mmol}$ ) and 4-(4-chlorophenyl)3-thiosemicarbazide ( $1.41 \mathrm{~g}, 7 \mathrm{mmol})$, anhydrous ethanol ( $20 \mathrm{~mL})$ and glacial acetic acid ( $79 \mathrm{mg}, 5 \mathrm{drops})$ were added. The reaction mixture was heated under reflux for $3 \mathrm{~h}$. After cooling, the precipitate was filtered off. After drying, precipitate was crystallized from acetic acid.

Yield $1.59 \mathrm{~g}(62 \%)$, orange powder, $\mathrm{mp}=198-200^{\circ} \mathrm{C} . \mathrm{IR} v\left(\mathrm{~cm}^{-1}\right)$ : $3294(\mathrm{NH}), 3054\left(\mathrm{CH}_{\mathrm{ar}}\right), 1589$, $1549(\mathrm{C}=\mathrm{N}) .{ }^{1} \mathrm{H}$ NMR $\left(300 \mathrm{MHz}, \mathrm{DMSO}-\mathrm{d}_{6}\right) \delta: 7.44(2 \mathrm{H}, \mathrm{d}, J=8.7 \mathrm{~Hz}, \mathrm{Ar} \mathrm{H}) ; 7.56(2 \mathrm{H}, \mathrm{d}, J=8.7 \mathrm{~Hz}$, Ar H); 8.29 (1H, s, CH=N); $10.12(1 \mathrm{H}, \mathrm{s}, \mathrm{NHCSNH}) ; 12.16$ (1H, s, NHCSNH). ${ }^{13} \mathrm{C}$ NMR $(75 \mathrm{MHz}$, DMSO-d $\left.{ }_{6}\right)$ 8: $128.1\left(\mathrm{CH}_{\text {ar. }}\right), 128.5\left(\mathrm{CH}_{\text {ar. }}\right), 130.1\left(\mathrm{C}_{\text {ar. }}\right), 130.5\left(\mathrm{C}_{\mathrm{ar}}\right), 133.3(\mathrm{CH}=\mathrm{N}), 136.9(\mathrm{~N}=\mathrm{CH}-\mathrm{C})$, $138.3(=\mathrm{C}(\mathrm{Cl})-\mathrm{N}), 152.6(\mathrm{~S}-\mathrm{C}(\mathrm{Cl})=\mathrm{N}), 176.6(\mathrm{C}=\mathrm{S})$. Anal. calc. for $\mathrm{C}_{11} \mathrm{H}_{7} \mathrm{Cl}_{3} \mathrm{~N}_{4} \mathrm{~S}_{2}$ (365.689) (\%): C 36.13; H 1.93; N 15.32. Found: C 36.07; H 1.89; N 15.27. 
3.3. Methyl [3-(4-chlorophenyl)-2-\{[(2,4-dichloro-1,3-thiazol-5-yl)methylidene]hydrazinylidene\}-4-oxo-1,3thiazolidin-5-ylidene]acetate (4)

To the thiosemicarbazone $3(0.73 \mathrm{~g}, 2 \mathrm{mmol})$ dimethyl acetylenedicarboxylate $(0.25 \mathrm{~mL}, 2 \mathrm{mmol})$ and methanol $(15 \mathrm{~mL})$ were added. The reaction mixture was heated under reflux for $30 \mathrm{~min}$. After cooling, the precipitate was filtered off. After drying, precipitate was crystallized from a mixture of solvents DMF/acetic acid in volume ratio (1/1).

Yield $0.62 \mathrm{~g}(65 \%)$, yellow powder, $\mathrm{mp}=248-250{ }^{\circ} \mathrm{C}$. IR $v\left(\mathrm{~cm}^{-1}\right): 3056\left(\mathrm{CH}_{\mathrm{ar}}\right), 1730(\mathrm{C}=\mathrm{O}$ ester), $1690(\mathrm{C}=\mathrm{O}$ thiazolidine $), 1587,1550(\mathrm{C}=\mathrm{N}) ;{ }^{1} \mathrm{H}$ NMR $\left(300 \mathrm{MHz}, \mathrm{DMSO}-d_{6}\right) \delta: 3.85(3 \mathrm{H}, \mathrm{s}$, $\left.\mathrm{OCH}_{3}\right) ; 6.94\left(1 \mathrm{H}, \mathrm{s}, \mathrm{H}_{3} \mathrm{COOC}-\mathrm{CH}=\right) ; 7.64(2 \mathrm{H}, \mathrm{d}, J=8.7 \mathrm{~Hz}, \mathrm{Ar} \mathrm{H}) ; 7.76(2 \mathrm{H}, \mathrm{d}, J=8.7 \mathrm{~Hz}, \mathrm{Ar} \mathrm{H})$; $8.30(1 \mathrm{H}, \mathrm{s}, \mathrm{CH}=\mathrm{N}) .{ }^{13} \mathrm{C}$ NMR $\left(75 \mathrm{MHz}, \mathrm{DMSO}-d_{6}\right) \delta: 53.3\left(\mathrm{OCH}_{3}\right) ; 117.1(\mathrm{CH}=\mathrm{C}) ; 122.3(\mathrm{CH}=\mathrm{C})$; $130.3\left(\mathrm{CH}_{\mathrm{ar}}\right) ; 131.1\left(\mathrm{CH}_{\mathrm{ar}}\right) ; 133.7\left(\mathrm{C}_{\mathrm{ar}}\right) ; 135.2(\mathrm{~N}=\mathrm{CH}-\mathrm{C}) ; 140.8(=\mathrm{C}(\mathrm{Cl})-\mathrm{N}) ; 141.3\left(\mathrm{C}_{\mathrm{ar}}\right) ; 145.9(\mathrm{CH}=\mathrm{N})$; $158.5(\mathrm{~S}-\mathrm{C}(\mathrm{Cl})=\mathrm{N}) ; 164.3(\mathrm{C}=\mathrm{N}) ; 164.6(\mathrm{C}=\mathrm{O}$ thiazolidine $) ; 166.4(\mathrm{C}=\mathrm{O}$ ester $)$. Anal. calc. for $\mathrm{C}_{16} \mathrm{H}_{9} \mathrm{Cl}_{3} \mathrm{~N}_{4} \mathrm{O}_{3} \mathrm{~S}_{2}$ (475.757) (\%): C 40.39; $\mathrm{H} 1.91 ; \mathrm{N}$ 11.78. Found: C 40.26; H 1.90; N 11.77.

\section{Conclusions}

The result of our current research is the new (4-oxothiazolidin-5-ylidene)acetic acid derivative. It has been synthesized in good yield from 4-(4-chlorophenyl)-1-(2,4-dichloro-1,3-thiazol-5-yl) methylidene-3-thiosemicarbazide by thia-Michael reaction with next cyclization. This compound can be of interest to the medicinal science branch due to its potential as an anti-T. gondii agent.

Supplementary Materials: The following are available online, Figures S1-S6: IR, ${ }^{1} \mathrm{H}$, and ${ }^{13} \mathrm{C}$ NMR spectra for compounds 3 and 4 .

Author Contributions: Conceptualization, N.T.; methodology, N.T.; formal analysis, N.T.; investigation, J.S., H.T. and N.T.; writing —original draft preparation, N.T.; writing—review and editing, N.T.; visualization, J.S., H.T.; supervision, N.T. All authors have read and agreed to the published version of the manuscript.

Funding: This research received no external funding.

Conflicts of Interest: The authors declare no conflict of interest.

\section{References}

1. Tenter, A.M.; Heckeroth, A.R.; Weiss, L.M. Toxoplasma gondii: From animals to humans. Int. J. Parasitol. 2000, 30, 1217-1258. [CrossRef]

2. Kaminskyy, D.; Kryshchyshyn, A.; Lesyk, R. 5-Ene-4-thiazolidinones-An efficient tool in medicinal chemistry. Eur. J. Med. Chem. 2017, 140, 542-594. [CrossRef] [PubMed]

3. Havrylyuk, D.; Roman, O.; Lesyk, R. Synthetic approaches, structure activity relationship and biological applications for pharmacologically attractive pyrazole/pyrazoline-thiazolidine-based hybrids. Eur. J. Med. Chem. 2016, 113, 145-166. [CrossRef] [PubMed]

4. Chadna, N.; Bahia, M.S.; Kaur, M.; Silakari, O. Thiazolidine-2,4-dione derivatives: Programmed chemical weapons for key protein targets of various pathological conditions. Bioorg. Med. Chem. 2015, 23, 2953-2974. [CrossRef] [PubMed]

5. Tripathi, A.C.; Gupta, S.J.; Fatima, G.N.; Sonar, P.K.; Verma, A.; Saraf, S.K. 4-Thiazolidinones: The advances continue ... Eur. J. Med. Chem. 2014, 72, 52-77. [CrossRef] [PubMed]

6. Jain, V.S.; Vora, D.K.; Ramaa, C.S. Thiazolidine-2,4-diones: Progress towards multifarious applications. Bioorg. Med. Chem. 2013, 21, 1599-1620. [CrossRef] [PubMed]

7. Verma, A.; Saraf, S.K. 4-Thiazolidinone-A biologically active scaffold. Eur. J. Med. Chem. 2008, 43, 897-905. [CrossRef] [PubMed]

8. Tenorio, R.P.; Carvalho, C.S.; Pessanha, C.S.; de Lima, J.G.; de Faria, A.R.; Alves, A.J.; de Melo, E.J.T.; Goes, A.J.S. Synthesis of thiosemicarbazone and 4-thiazolidinone derivatives and their in vitro anti-Toxoplasma gondii activity. Bioorg. Med. Chem. Lett. 2005, 15, 2575-2578. [CrossRef] [PubMed] 
9. De Aquino, T.M.; Liesen, A.P.; da Silva, R.E.A.; Lima, V.T.; Carvalho, C.S.; de Faria, A.R.; de Araujo, J.M.; de Lima, J.G.; Alves, A.J.; de Melo, E.J.T.; et al. Synthesis, anti-Toxoplasma gondii and antimicrobial activities of benzaldehyde 4-phenyl-3-thiosemicarbazones and 2-[(phenylmethylene)hydrazono]-4-oxo3-phenyl-5-thiazolidineacetic acids. Bioorg. Med. Chem. 2008, 16, 446-456. [CrossRef] [PubMed]

10. Liesen, A.P.; de Aquino, T.M.; Carvalho, C.S.; Lima, V.T.; de Araujo, J.M.; de Lima, J.G.; de Faria, A.R.; de Melo, E.J.T.; Alves, A.J.; Alves, E.W.; et al. Synthesis and evaluation of anti-Toxoplasma gondii and antimicrobial activities of thiosemicarbazides, 4-thiazolidinones and 1,3,4-thiadiazoles. Eur. J. Med. Chem. 2010, 45, 3685-3691. [CrossRef] [PubMed]

11. Carradori, S.; Secci, D.; Bizzarri, B.; Chimenti, P.; De Monte, C.; Guglielmi, P.; Campestre, C.; Rivanera, D.; Bordon, C.; Jones-Brando, L. Synthesis and biological evaluation of anti-Toxoplasma gondii activity of a novel scaffold of thiazolidinone derivatives. J. Enzyme Inhib. Med. Chem. 2017, 32, 746-758. [CrossRef] [PubMed]

12. Trotsko, N.; Bekier, A.; Paneth, A.; Wujec, M.; Dzitko, K. Synthesis and in vitro anti-Toxoplasma gondii activity of novel thiazolidin-4-one derivatives. Molecules 2019, 24, 3029. [CrossRef] [PubMed]

13. Kotlyar, V.N.; Pushkarev, P.A.; Orlov, V.D.; Chernenko, V.N.; Desenko, S.M. Thiazole analogs of chalcones, capable of functionalization at the heterocyclic nucleus. Chem. Heterocycl. Compd. 2010, 46, 334-341. [CrossRef]

(C) 2020 by the authors. Licensee MDPI, Basel, Switzerland. This article is an open access article distributed under the terms and conditions of the Creative Commons Attribution (CC BY) license (http://creativecommons.org/licenses/by/4.0/). 